DOI 10.31558/2307-2318.2020.3.11
УДК 336.201
JЕL: H21, L26, M21

Карпова Т.C., к.е.н., доцент, доцент кафедри фінансів і банківської справи, Донецький національний університет імені Василя Стуса

ORCID: 0000-0003-3701-8194

t.karpova@donnu.edu.ua

\title{
МЕХАНІЗМ ЕФЕКТИВНОГО ФУНКЦІОНУВАННЯ ПШДПРИЕМСТВ: ПОДАТКОВИЙ АСПЕКТ
}

Ефективне функиіонування - мета як макроекономічних суб’єктів, так $i$ мікроекономічних. Досягнення показників, які свідчать про ефективне функціонування, залежить від багатьох факторів. Одним із інструментів, який забезпечує ефективне функиіонування є система оподаткування та податкова політика в иілому. Система оподаткування має бути такою, щуо не тільки забезпечує стабільні надходження до бюджету, а й враховує особливості суб'єктів господарювання, стимулює їх розвиток.

Як великі акціонерні товариства, так і малі підприємства мають певний рівень податкових обов'язків, виконання яких відбивається на фінансово-економічних показниках підприємства. 3 огляду на те, щьо досягнення ефективності - складний механізм взаємозв'язків, важливим є розгляд впливу податкового аспекту на забезпечення високих результатів фінансово-господарської діяльності. Стаття присвячена питанням механізму ефективного функціонування підприємств, зокрема податковому аспекту. Визначені принципи цьього механізму, а також структурні елементи організаційної системи забезпечення розвитку малого бізнесу на державному та регіональному рівнях. Розглянуто напрямки вдосконалення нормативно-правового забезпечення. Розроблено податковий механізм стимулювання суб'єктів господарювання.

Ключові слова: ефективність, система оподаткування, податковий механізм, стимулювання бізнесу, розвиток бізнесу, підприємства.

Рис. - 1, Табл. - 1, Літ. - 8.

\section{Карпова T.C.,}

к.э.н, доцент, доцент кафедры финансов и банковского дела, Донецкий национальный университет имени Васыля Стуса

ORCID: 0000-0003-3701-8194

t.karpova@donnu.edu.ua

\section{МЕХАНИЗМ ЭФФЕКТИВНОГО ФУНКЩИОНИРОВАНИЯ ПРЕДПРИЯТИЙ: НАЛОГОВЫЙ АСПЕКТ}

Эффрективное функиионирование - иель как макроэкономических субъектов, так и микроэкономических. Достижение показателей, которые свидетельствуют об 
эффрективном функционировании, зависит от многих фракторов. Одним из инструментов, который обеспечивает эффективное функиионирование является система налогообложения и налоговая политика в иеелом. Система налогообложения должна быть такой, что не только обеспечивает стабильные поступления в бюджет, но и учитывает особенности субъектов хозяйствования, стимулирует их развитие.

Как крупные акционерные общества, так и малье предприятия имеют определенный уровень налоговых обязанностей, выполнение которых отражается на финансово-экономических показателях предприятия. Учитывая то, что достижение эффективности - сложный механизм взаимосвязей, важным является рассмотрение влияния налогового аспекта на обеспечение высоких результатов финансовохозяйственной деятельности. Статья посвящена вопросам механизма эффрективного функиионирования предприятий. Обозначень принципь данного механизма, а также структурные элементы организационной системы обеспечения развития малого бизнеса на государственном и региональном уровнях. Рассмотрень направления совершенствования нормативно-правового обеспечения. Разработан налоговый механизм стимулирования субъектов хозяйствования.

Ключевые слова: эффективность, система налогообложения, налоговый механизм, стимулирование бизнеса, развитие бизнеса, предприятия.

Рис. - 1, Табл. - 1, Лит. - 8.

\section{T. Karpova,}

Ph.D., Associate Professor of finance and banking department, Vasyl' Stus Donetsk National University

ORCID: 0000-0003-3701-8194

t.karpova@donnu.edu.ua

\section{MECHANISM OF EFFICIENT FUNCTIONING OF ENTERPRISES: TAX ASPECT}

Efficient functioning is the goal of both macroeconomic and microeconomic entities. Achieving indicators that demonstrate efficient functioning depends on many factors. One of the tools that ensures effective functioning is the tax system and tax policy in general. The taxation system should be such that not only ensures stable budget revenues, but also takes into account the characteristics of business entities and stimulates their development.

Both large joint-stock companies and small enterprises have a certain level of tax obligations, the performance of which is reflected in the financial and economic indicators of the enterprise. Taking into account the fact that achievement of efficiency is a complicated mechanism of interrelations, it is important to consider the impact of the tax aspect on ensuring high results of financial and economic activity. The article is devoted to the mechanism of efficient functioning of enterprises. The principles of this mechanism are defined, as well as the structural elements of the organizational system for ensuring the development of small business at the state and regional levels. The directions of improvement of normative-legal support are considered. The tax mechanism of stimulation of economic entities was developed.

Keywords: efficiency, taxation system, tax mechanism, business stimulation, business development, enterprises.

Fig. - 1, Tab. - 1, Ref. - 8 
Постановка проблеми та її зв'язок з важливими науковими чи практичними завданнями. Розвиток та ефективне функціонування суб'єктів господарювання залежить від багатьох факторів, вагому роль серед яких займає система оподаткування. В залежності від форм власності та розміру підприємств податкове навантаження на підприємство може бути більш або менш відчутним, проте прямо впливає на результати фінансово-господарської діяльності. Для великих акціонерних товариств сумлінне дотримання всіх вимог податкового законодавства спричиняє великі обсяги відволікання коштів. Великі підприємства мають значні ризики пильної уваги зі сторони контролюючих органів, що випливає з того, що від таких підприємств очікується значні надходження до бюджетів різних рівнів. Оподаткування фінансового результату може спричиняти зменшення основних показників: ліквідності, рентабельності активів, розміру власного капіталу через зменшення обсягу нерозподіленого прибутку тощо. Проте особливо гостро це питання постає для малого бізнесу.

В сучасних умовах малий бізнес сприяє економічній і соціальній стабільності суспільства, виконуючи важливі економічні та соціальні функції, сприяючи насиченню товарного ринку, розвитку конкурентного середовища, структурній перебудові виробництва і суспільства, беручи участь у формуванні ВВП і доходів бюджетів всіх рівнів, забезпечуючи зайнятість населення i збільшення його доходів. Всебічна підтримка суб'єктів малого бізнесу з метою підвищення їх конкурентоспроможності $\epsilon$ одним 3 найважливіших заходів зниження соціальної напруженості і забезпечення економічної безпеки держави.

Аналіз останніх досліджень і публікацій 3 проблеми, що розглядається. Особливості розвитку малого бізнесу вивчали провідні зарубіжні та вітчизняні вчені. Серед них М. Вебер, В. Зомбарт, Й. Шумпетер, Л. Мізес, Р. Хизрич, А. Хоскинг, А.М. Бабич, 3.С. Варналій, В.І. Ляшенко, С.К. Реверчук, Л.П. Хмелевська, В.Л. Іноземцев, В.М. Новиков, Л.С. Співак та інші. Питання розробки механізму розвитку малого бізнесу в даний момент є недостатньо освітленими і дискусійними, що свідчить про необхідність переосмислення вітчизняного досвіду функціонування малого бізнесу, перетворення його в фактор економічного зростання, збереження і примноження конкурентних переваг України.

Метою статті $\epsilon$ розробка механізму ефективного функціонування малих підприємств в сучасних умовах, зокрема податкового механізму стимулювання суб'єктів малого бізнесу.

Виклад основного матеріалу статті з обгрунтуванням отриманих наукових результатів. Серед багатьох факторів впливу на ефективність функціонування підприємств значне місце відводиться податкам. Різноманітність податків та їх ставок, об'єкти оподаткування, строки сплати, штрафні санкції безпосередньо впливають на фінансово-економічні показники діяльності суб' єктів господарювання.

Система оподаткування $є$ важливим питанням у функціонуванні підприємств всіх розмірів та форм власності. Для акціонерних товариств, наприклад, з метою оптимізації оподаткування та підвищення ефективності суттєвим $є$ питання оподаткування отриманого прибутку. Впроваджуючи податок на виведений капітал, оподаткуванню належить низка операцій, серед яких, наприклад, $є$ виплата дивідендів на користь неплатника податку. Система оподаткування, яка передбачає капіталізацію прибутку підприємств, мінімізує обсяг податкового зобов'язання, одночасно прискорюючи розвиток підприємства, рівень показників, що свідчать про ефективну діяльність підприємства, i, як наслідок позитивно впливає на економіку держави в цілому. 
Система оподаткування України передбачає два види: загальна система та спрощена. Спрощена система спрямована в першу чергу на підтримку малого бізнесу шляхом запровадження більш низьких ставок податків, зменшення витрат на ведення обліку. Разом з тим, періодично держава надає податкові пільги підприємствам певних галузей. 3 огляду на необхідність підтримки у різні часи того чи іншого сектору економіки, деякі елементи оподаткування, що застосовуються для малих підприємств можуть бути цікавими для великих та середніх суб'єктів господарювання.

Механізм ефективного функціонування малих підприємств заснований на методах системного підходу, економіко-статистичного моделювання і прогнозування, на синтезі ефективних форм, методів та інструментів управління малими підприємствами, що передбачає державну i недержавну підтримку малого бізнесу i системи його забезпечення, дозволяє активізувати його розвиток і вплив на соціальну сферу i підвищити добробут суспільства. Механізм ефективного функціонування малих підприємств повинен базуватися на таких основних принципах [1]:

- наукової обгрунтованості, тобто в процесі вибору механізму розвитку малого бізнесу необхідно враховувати дію об'єктивних економічних законів, специфіку розвитку економіки країни, соціального та політичного життя суспільства, історичні та національні особливості становлення і розвитку малого бізнесу;

- комплексності, яка виражається як у розробці теоретичних основ пріоритетних напрямків розвитку малого бізнесу, так i у визначенні найбільш ефективних, оптимальних для даного етапу розвитку економіки тактичних прийомів і методів їх реалізації;

- системному підході, що виражається в розробці і використанні форм, інструментів, методів, прийомів і способів реалізації зазначеного механізму;

- об’єктивності, що передбачає дослідження факторів, що впливають на функціонування і розвиток малого бізнесу;

- доцільності та цілеспрямованості, що має на увазі чітку адресність підтримки малого бізнесу з визначенням мети, пріоритетів, напрямків, форм і способів їх реалізації, а також їх реальне ресурсне забезпечення в необхідних обсягах;

- безперервності, що вимагає постійного розвитку малого бізнесу;

- динамічності: розробка зазначеного механізму - процес, що постійно розвивається і удосконалюється;

- координації взаємодії всіх елементів механізму, рівнів і форм підтримки, систем забезпечення малого бізнесу;

- оптимальності, яка передбачає вибір оптимальних напрямів і диверсифікацію підходів і рішень в процесі підтримки малого бізнесу;

- ефективності, яка передбачає результативність загальнодержавних i регіональних програм розвитку малого підприємництва.

Основною метою зазначеного механізму є підвищення ролі та значення малого бізнесу в розвитку національної економіки, зміцнення його конкурентоспроможності на вітчизняному та міжнародних ринках і посилення впливу на економічні та соціальні процеси в суспільстві.

Поставлена мета і сформульовані принципи дозволять вирішити такі завдання:

- забезпечити зростання кількісних показників економічного i соціального розвитку суспільства за рахунок діяльності малого бізнесу: зростання ВВП, збільшення кількості суб'єктів малого бізнесу, скорочення безробіття, збільшення надходжень до бюджету від суб' єктів малого бізнесу;

- сприяти розвитку конкуренції та обмеження монополізму; 
- забезпечити інноваційний розвиток малого бізнесу на основі його технічного i технологічного переозброєння;

- сприяти зростанню конкурентоспроможності малого бізнесу;

- зміцнити соціальне партнерство і підвищити соціальну відповідальність малого бізнесу.

Для реалізації перерахованих вище завдань необхідно створити дієвий механізм розвитку малого бізнесу 3 метою активізації людського фактору, гнучкого по відношенню до зовнішнього середовища управління суб' єктами малого бізнесу, їх всебічної державної і недержавної підтримки. Це забезпечить малим підприємствам достатню ефективність і конкурентоспроможність на вітчизняному та міжнародних ринках, посилить їх вплив на економічні та соціальні процеси в суспільстві. Механізм розвитку малого бізнесу є об' єктом управління державної політики розвитку малого підприємництва на загальнонаціональному та регіональному рівнях, який реалізується за допомогою таких основних функцій управління як організація, аналіз, контроль, регулювання, стимулювання [2].

Становлення і функціонування малого бізнесу в Україні має свої особливості, зумовлені дією ряду зовнішніх і внутрішніх факторів, що визначає специфіку реалізації перерахованих функцій управління розвитком малого бізнесу. На сучасному етапі динаміка і основні тенденції розвитку малого бізнесу в Україні свідчать про вплив негативних чинників, що гальмують процес розвитку, і про відсутність ефективної системи управління ними на загальнодержавному, регіональному та місцевому рівнях.

Механізм розвитку малого бізнесу базується на нормативно-правовій, організаційній, фінансово-кредитній, ресурсній та інформаційній системах його забезпечення.

Нормативно-правове забезпечення лежить в основі функціонування малого бізнесу. Держава, створюючи нормативно-правове середовище діяльності малого бізнесу, з одного боку, забезпечує йому економічну свободу, надає права і гарантії на заняття законною підприємницькою діяльністю. 3 іншого боку, воно визначає обов'язки і встановлює відповідальність малого бізнесу (перед іншими суб'єктами підприємництва, бюджетом, банківською системою, населенням) за виконання зобов'язань в належному обсязі і в установлені терміни. Система нормативноправового забезпечення, що регулює підприємницьку діяльність і надає гарантії на володіння власністю, функціонально обов'язкове для всіх суб'єктів малого бізнесу. Тому безсистемність нормативно-правового поля i суперечливість окремих нормативно-правових документів обумовлені, перш за все, відсутністю узгодженої державної стратегії розвитку малого бізнесу. Це істотно стримує його розвиток, породжує проблеми і протиріччя, які знижують ефективність його діяльності. У більшості випадків чинні нормативно-законодавчі акти, що регулюють підприємницьку діяльність, доповнюються і уточняються нормативними актами різних міністерств, відомств і органів виконавчої влади всіх рівнів. Незважаючи на прийняті за останні роки нормативно-правові документи, що позитивно вплинули на розвиток малого бізнесу, система нормативно-правового забезпечення розвитку малого бізнесу потребує подальшого вдосконалення. Воно повинно здійснюватися в напрямку зміцнення взаємодії між центральними, регіональними та місцевими органами державної влади і малим бізнесом для оптимізації впливу нормативноправового середовища на його розвиток. 
Удосконалення системи нормативно-правового забезпечення розвитку малого бізнесу пропонується здійснювати за такими основними напрямками:

- розробка і прийняття нових нормативно-правових документів, що регулюють діяльність малого бізнесу з метою його підтримки і розвитку на основі надання суб'єктам малого бізнесу реальних правових гарантій, що забезпечують свободу і захист їх економічної діяльності;

- вдосконалення діючих нормативно-правових актів, що регулюють діяльність малого бізнесу, для ліквідації суперечливості окремих нормативно-правових актів та положень, які стримують його розвиток;

- формування узгодженої державної стратегії розвитку малого бізнесу і його законодавчого забезпечення на основі органічного поєднання теорії та практики розвитку вітчизняного малого бізнесу i використання зарубіжного досвіду 3 урахуванням наших національних і історичних особливостей;

- проведення постійного моніторингу нормативно-правових актів, що регулюють підприємницьку діяльність [3].

Система організаційного забезпечення розвитку малого бізнесу передбачає наявність організаційних інструментів впливу на діяльність суб'єктів малого підприємництва, що приводяться в дію органами загальнодержавного, регіонального і місцевого управління.

Система організаційного забезпечення розвитку малого бізнесу досить динамічна, їі структурні елементи, які прямо або побічно здійснюють управління розвитком малого бізнесу на державному, регіональному та місцевому рівнях, змінюються іноді по кілька разів протягом року під впливом як об'єктивних, так і суб'єктивних причин.

В даний час система організаційного забезпечення розвитку малого бізнесу включає структурні елементи, представлені в табл. 1.

Таблиця 1

\section{Структурні елементи організаційної системи забезпечення розвитку малого бізнесу}

\begin{tabular}{|c|c|}
\hline На державному рівні & На регіональних рівнях \\
\hline $\begin{array}{l}\text { Державний комітет Украӥни з } \\
\text { питань регуляторної політики та } \\
\text { підприємництва }\end{array}$ & $\begin{array}{l}\text { координаційні ради з питань розвитку підприємництва при обласних } \\
\text { державних адміністраціях; } \\
\text { територіальні } \quad \text { представництва } \quad \text { державного п підприємництва; } \\
\text { інститути уповноважених з питань захисту прав підприємців. }\end{array}$ \\
\hline $\begin{array}{l}\text { Міністерство економічного } \\
\text { розвитку, торгівлі та сільського } \\
\text { господарства України }\end{array}$ & $\begin{array}{l}\text { головні управління економіки при обласних } \\
\text { адміністраціях та їх структурних підрозділів. }\end{array}$ \\
\hline $\begin{array}{l}\text { Антимонопольний } \quad \text { комітет } \\
\text { України }\end{array}$ & $\begin{array}{l}\text { обласні територіальні відділення Антимонопольного комітету } \\
\text { України; регіональні фонди підтримки малого підприємництва. }\end{array}$ \\
\hline Міністерство фінансів Украӥни & $\begin{array}{l}\text { незалежні державні, змішані та приватні фонди розвитку малого } \\
\text { бізнесу, бізнес-центри, інноваційні бізнес-інкубатори, науково- } \\
\text { технологічні центри, центри трансферту технологій, лізингові } \\
\text { компанії, консультативні центри. }\end{array}$ \\
\hline Фонд державного майна Украӥни & $\begin{array}{l}\text { регіональні відділення Фонду державного майна України; } \\
\text { комерційні банки, інвестиційні компанії і фонди; страхові компанії; } \\
\text { спеціалізовані кредитно-гарантійні установи. }\end{array}$ \\
\hline $\begin{array}{l}\text { Український фонд підтримки } \\
\text { підприємництва }\end{array}$ & регіональні фонди підтримки підприємництва. \\
\hline $\begin{array}{l}\text { Державна служба зайнятості } \\
\text { Украӥни }\end{array}$ & $\begin{array}{l}\text { обласні центри зайнятості, громадські організації з підтримки і } \\
\text { сприяння розвитку малого підприємництва: асоціації та спілки } \\
\text { підприємців, центри сприяння розвитку малого бізнесу. }\end{array}$ \\
\hline Пенсійний фонд України & головні управління Пенсійного фонду України в областях \\
\hline
\end{tabular}


Основним завданням органів, які здійснюють сприяння розвитку малого бізнесу на державному рівні, $є$ розробка єдиних підходів до організації його підтримки, визначення пріоритетів допомоги суб'єктам малого підприємництва, розробка і реалізація відповідної державної політики і іï фінансове забезпечення [4].

Основними завданнями органів підтримки розвитку малого підприємництва на регіональному рівні є: створення сприятливого середовища для його розвитку, розробка і реалізація на основі соціального партнерства регіональних і місцевих програм розвитку малого підприємництва; формування і розвиток інфраструктури підтримки малого бізнесу, координація діяльності всіх елементів системи малого бізнесу [5].

Система фінансово-кредитного забезпечення розвитку малого бізнесу базується на комплексі заходів, спрямованих на використання об'єктивно існуючих економічних законів з управління фінансовими відносинами і фінансовими ресурсами, за допомогою методів і форм організації фінансових відносин суб'єктів малого бізнесу для їх динамічного розвитку, економічного і соціального розвитку суспільства в цілому. Вітчизняний і зарубіжний досвід свідчить про те, що істотними факторами, що стримують розвиток малого бізнесу, $є$ недолік власного стартового капіталу, податковий тиск і труднощі залучення позикових коштів. Незважаючи на основний принцип фінансового забезпечення підприємництва, заснованого на самоокупності i самофінансуванні, внутрішніх джерел фінансових ресурсів для успішного розвитку бізнесу, як правило, недостатньо. Однак в даний час малий бізнес продовжує зазнавати труднощів при доступі до ресурсів банківської системи і ринку цінних паперів, що в умовах дефіциту ліквідності і капіталів погіршує їх фінансовий стан, істотно знижує їх конкурентоспроможність в порівнянні з великими підприємствами. Оскільки саме фінансово-кредитні чинники мають першочергове значення в становленні і розвитку малого бізнесу, то йому об'єктивно необхідна державна і недержавна фінансовокредитна підтримка на загальнонаціональному та регіональному рівнях. Ця підтримка повинна бути всебічною, реальною і спрямованою, перш за все, на забезпечення фінансової самостійності суб'єктів малого бізнесу та створення сприятливих умов для їх розвитку та зміцнення конкурентоспроможності на вітчизняному та міжнародних ринках.

Система ресурсного забезпечення значно впливає на розвиток малого бізнесу, формуючи його економічне середовище. В умовах нестачі інформації про наявність ресурсів і умов їх надання, значною мірою монополізації вітчизняного ринку нерухомості, недотримання принципу відкритого надання ресурсів на конкурсній основі, надання обладнання та нерухомості в оренду в основному на короткостроковий період і на невигідних для малого бізнесу умовах, його доступ до природним, сировинним, матеріально-технічним, трудовим i інформаційних ресурсів в даний час надзвичайно ускладнений. І незважаючи на те, що ринок засобів виробництва і сировини в даний час істотно пожвавився в порівнянні з ринком нерухомості, дефіцит фінансових ресурсів у суб'єктів малого бізнесу не дозволяє їм на рівних з великими підприємствами отримувати доступ до цих ресурсів. Тому для створення рівних конкурентних можливостей малого і великого бізнесу регіональні та місцеві органи влади і управління покликані надавати малим підприємствам підтримку в розвитку їх виробничої бази, організації матеріально-технічного забезпечення. Це сприяння здійснюється шляхом надання допомоги в оренді виробничих і нежитлових приміщень, виділення земельних ділянок, передачі законсервованих i недобудованих об'єктів, невикористаного устаткування і т.д. Для суб'єктів малого підприємництва доцільно використовувати також систему пільг і стимулів з метою зниження тарифів на воду і електроенергію, 
платежів за сировину і матеріали, оренду території або приміщень. Активної участі суб'єктів малого бізнесу у вирішенні економічних і соціальних проблем регіонів сприяє також розміщення серед них державних замовлень.

Сьогодні податки $є$ основним фінансовим інструментом, який регулює взаємовідносини малого, середнього i великого бізнесу 3 державою. Питання оподаткування малого і середнього бізнесу - один з найбільш актуальних в Україні. Саме $з$ розвитком малого і середнього підприємництва пов'язана велика кількість заходів, здійснюваних органами державної влади для вирішення економічних i соціальних проблем нашої країни. В Україні оподаткування малого бізнесу з метою розвитку цього сектора економіки має виконувати такі функції: сприяти формуванню конкурентного середовища; підтримувати гнучкість ринкової економіки за рахунок прогнозованої та стабільної законодавства і адекватного податкового тиску; вирішувати проблеми зайнятості за рахунок зменшення податкового навантаження на фонд оплати праці; створювати сприятливий соціально-економічний клімат за рахунок збалансованого податкового законодавства.

Стимулюючий характер політики держави в сфері оподаткування малого бізнесу, як складової частини загальнодержавної політики підтримки цього сектора економіки, можна забезпечити тільки за умови врахування особливостей малого бізнесу i відповідності його насущним потребам.

Ми поділяємо точку зору вчених-економістів про те, що для суб'єктів малого підприємництва, на відміну від великого бізнесу, виконання вимог податкового законодавства обходиться значно дорожче [6]. Підприємці крім реальних і справедливих ставок оподаткування, потребують простої податковій системі, яка дасть можливість легко дотримуватися правил i економити час i кошти на вирішення питань оподаткування. Чітке і стабільне податкове законодавство дозволить їм уникнути дискримінаційної трактування податкових законів і актів, а також дасть можливість планувати процес виконання своїх податкових зобов'язань. Саме це визначає основні вимоги до механізму оподаткування малого бізнесу. Ці вимоги такі: реальний рівень податкового навантаження; простота і прозорість правил оподаткування; стабільність положень податкового законодавства; простота визначення податкової бази; мінімізація процедур обліку; простота і прозорість процедур контролю [7, с. 254].

У сучасних умовах формування і вдосконалення системи оподаткування малого бізнесу $€$ важливою проблемою, вирішення якої суттєво впливає на розвиток підприємництва, наповнення бюджетів усіх рівнів, підвищення інвестиційної активності в різних галузях національної економіки і соціальне життя суспільства.

3 огляду на рекомендації зарубіжних фахівців можна запропонувати ряд заходів, які дозволять стимулювати розвиток малого бізнесу шляхом зниження і перерозподілу податкового навантаження:

-збереження режиму спрощеного оподаткування, обліку та звітності для суб'єктів підприємництва, оскільки бізнес готовий платити більше в обмін на простоту i відсутність корупційної складової;

-диференціація ставок єдиного податку в залежності від рентабельності бізнесу і галузі;

-скасування заборони на використання єдиного податку в інтернет-торгівлі та виробництві програмних продуктів: в сучасних умовах держава повинна стимулювати розвиток IT-ринку, оскільки ця галузь перспективна як в світі, так і в Україні. 


\section{Принципи}

1. Обов`язковість оподаткування та відповідальність за порушення податкового законодавства;

2. Простота і стабільність податкового законодавства

3. Сдиний підхід до платників податків незалежно від масштабів діяльності;

4. Нейтральність оподаткування для конкурентоспроможності суб єктів малого бізнесу;

5. Реальний рівень податкового навантаження;

6. Мінімізація процедур податкового обліку;

7. Простота нарахування, сплати податків і подання податкової звітності.

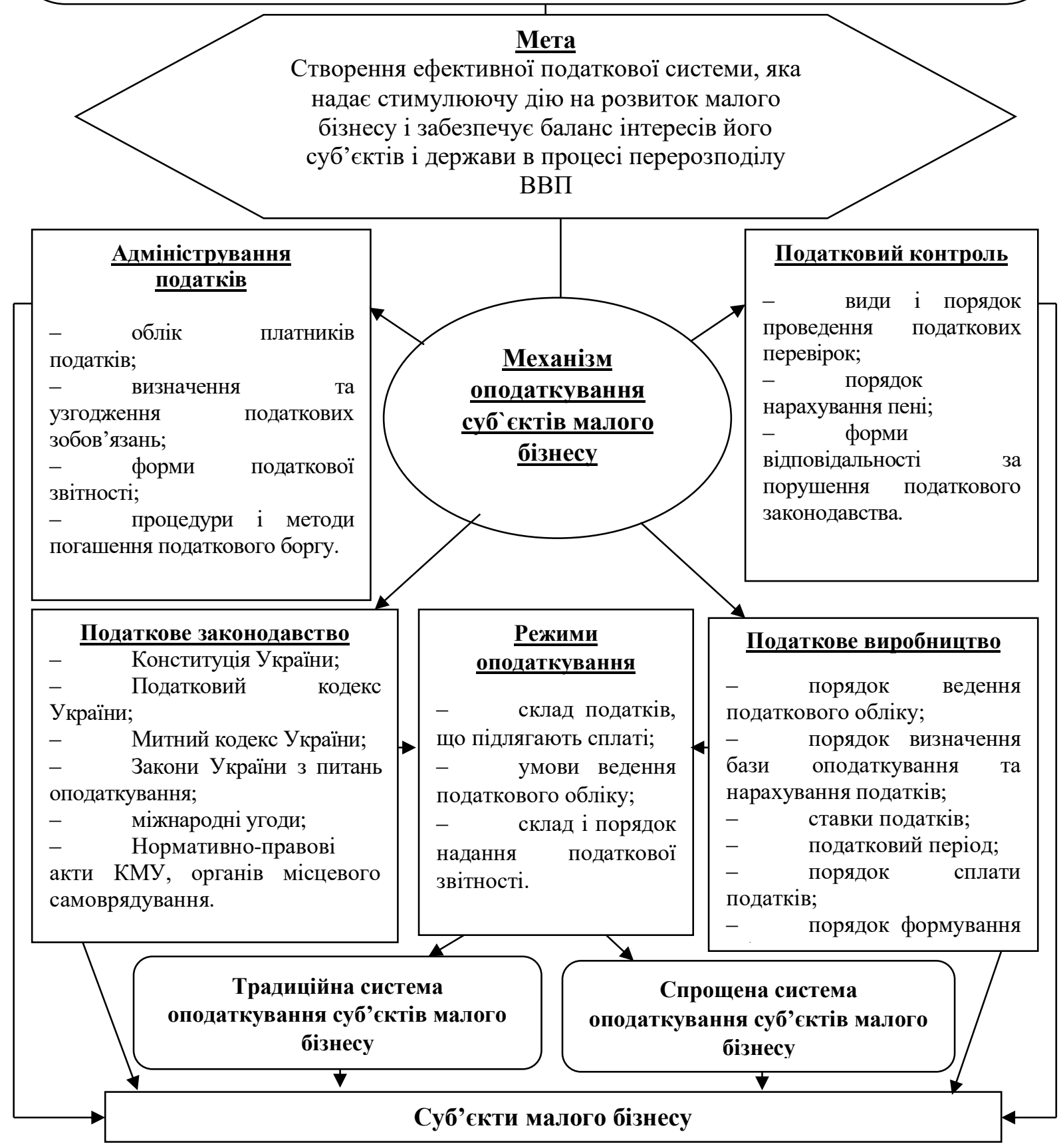

Рисунок 1 - Податковий механізм стимулювання суб'єктів малого бізнесу 
Необхідно відзначити, що певні елементи запропонованих заходів можуть бути цікавими не тільки для малих підприємств, а й для середніх та великих підприємств, які функціонують у суспільно-значущих сферах. Фінансовий стан великих суб'єктів господарювання, які є об'єктами критичної інфраструктури (енергетика, хімічна промисловість, транспорт тощо), та забезпечують населення життєво важливими послугами, може зазнавати складнощів внаслідок першочергового виконання інтересів споживачів, і тільки після того інтересів власника. Тобто, інтереси споживачів певною мірою превалюють над інтересами власників. За таких обставин, система оподаткування таких підприємств має враховувати особливість сфери, в якій вони функціонують. Збалансована система оподаткування для таких підприємств та для їх клієнтів - запорука сприятливого соціально-економічного клімату, що є безумовно важливим в цілому для України, Конституцією якої встановлено соціальну спрямованість економіки.

На основі аналізу існуючої системи оподаткування, на рис. 1 нами представлений податковий механізм стимулювання суб'єктів малого бізнесу, який спрямований на створення ефективної податкової системи, оскільки передбачає свободу вибору режиму оподаткування, що відрізняється кількістю сплачуваних податків, повнотою ведення податкового обліку та складання податкової звітності.

Висновки. Система оподаткування підприємств - один із факторів, які впливають на показники діяльності бізнесу, свідчать про рівень їх ефективності. Податки є невід'ємною частиною господарювання підприємств різних розмірів та різних форм власності.

Важливо відмітити, що окремі елементи оподаткування, що розглядаються як інструмент підвищення ефективності, також мають бути розглянуті на предмет можливості застосування середніми та великими підприємствами, які здійснюють діяльність у соціально-значущих галузях.

Врахування системою оподаткування соціальної орієнтованості, яка $є$ більш високою для певних підприємств, буде сприяти процесу забезпечення стабільної діяльності та потенційного здійснення інвестицій у розвиток критичної інфраструктури. Такий підхід, зокрема, забезпечує виконання соціальної спрямованості економіки. Процеси, пов'язані з оподаткуванням, безумовно впливають на показники фінансовоекономічної діяльності великих, середніх та малих підприємств.

Посилити стимулюючий вплив податкового механізму на розвиток суб'єктів малого підприємництва допоможе закордонний досвід, зокрема, досвід країн Європейського союзу, де механізм оподаткування суб' єктів малого підприємництва передбачає не тільки звільнення деяких видів підприємств від необхідності ведення обліку про результати господарської діяльності та запровадження спрощеної системи бухгалтерського обліку та звітності, а й впровадження спеціальних режимів оподаткування окремих категорій підприємств податком на додану вартість, а також використання податків на оціночний дохід.

У зв’язку з цим вдосконалення механізму оподаткування малого бізнесу доцільно в наступних напрямках:

- зниження і перерозподіл загального рівня податкового навантаження;

- реформування механізму непрямого оподаткування та вдосконалення порядку нарахування та справляння податків на споживання;

- оптимізація форм і методів податкового контролю діяльності суб'єктів малого бізнесу;

- впорядкування діючих податкових пільг для суб'єктів підприємництва. Пільги повинні мати цільове призначення, бути обмеженими в часі і забезпечувати 
інвестиційну та соціальну спрямованість механізму оподаткування малого бізнесу;

- розширення можливості використання суб'єктами малого бізнесу пільги «податкові канікули» [8].

Запропоновані рекомендації дозволять використовувати податкові важелі для стимулювання розвитку суб'єктів малого бізнесу, їх соціальної активності i наповнення бюджетів усіх рівнів.

\section{СПИСОК ВИКОРИСТАНИХ ДЖЕРЕЛ}

1. Карпова Т.С. Концепція механізму взаємообумовленого розвитку малого бізнесу та соціальної сфери. СХІД. 2013 № 6 (126). С. 99-104.

2. Battilana, J., and T. Casciaro. Change Agents, Networks, and Institutions: A Contingency Theory of Organizational Change. Academy of Management Journal. 2012.55 (2): p. 381398.

3. Medium-Sized Businesses: A Demand Perspective. Entrepreneurship \& Regional Development 15 (3): 229-252. GEM (Global Entrepreneurship Monitor). 2014. Informe GEM España 2013. Red Española de Equipos Regionales . http://www.gemconsortium.org/. 4. Національна програма сприяння розвитку малого підприємництва в Україні URL: http://www.kmu.gov.ua/control/uk/publish/article?art_id=246628657\&cat_id=244276429

5. Carrasco-Monteagudo, I., and I. Buendía-Martínez. 2013. "Corporate Social Responsibility: A Crossroad between Changing Values, Innovation and Internationalisation.” European Journal of International Management 7 (3): p. 295-314.

6. Вишневський В.П. До питання про ідею єдиного податку. Фінанси України. 2000. №7. C.11-17.

7. Чубарева Л.И. Этапы формирования в Украине механизма налогообложения субъектов малого бизнеса: противоречия и механизм их разрешения. Економіка, менеджмент, підприємництво: збірник наукових праць. 2005. №14 (1). С. 253 - 259.

8. Карпова Т.С. Роль налогообложения субъектов малого бизнеса в развитии социальной сферы. Фінансовий і банківський менеджмент: досвід та проблеми: тези доповідей і виступів XIV Міжнародної наукової конференції студентів і молодих вчених Донецьк: Юго- Восток, 2012. С. 121-123.

\section{REFERENCES}

1. Karpova, T.S. (2013). Kontseptsiia mekhanizmu vzaiemoobumovlenoho rozvytku maloho biznesu ta sotsialnoi sfery. SKhID. Analitychno-informatsiinyi zhurnal № 6 (126), $99-104$.

2. Battilana, J., and T. Casciaro. (2012). Change Agents, Networks, and Institutions: A Contingency Theory of Organizational Change. Academy of Management Journal 55 (2): 381-398. doi: http://dx.doi.org/10.5465/amj.2009.0891

3. Medium-Sized Businesses: A Demand Perspective." Entrepreneurship \& Regional Development 15 (3): 229-252. GEM (Global Entrepreneurship Monitor). 2014. Informe GEM España 2013 [GEM Spain Report 2013]. Red Española de Equipos Regionales [Spanish Network of Regional Teams]. http://www.gemconsortium.org/.

4. Natsionalna prohrama spryiannia rozvytku maloho pidpryiemnytstva v Ukraini. URL: http://www.kmu.gov.ua/control/uk/publish/article?art_id=246628657\&cat_id=244276429

5. Carrasco-Monteagudo, I., and I. Buendía-Martínez (2013). Corporate Social Responsibility: A Crossroad between Changing Values, Innovation and Internationalisation. European Journal of International Management 7 (3): 295-314.

6. Vyshnevskyi V.P. Do pytannia pro ideiu yedynoho podatku Finansy Ukrainy. 2000. 
№7, 11-17.

7. Chubareva L.I. Etapy formirovaniia v Ukraine mekhanizma nalogooblozheniia subektov malogo biznesa: protivorechiia i mekhanizm ikh razresheniia Ekonomika, menedzhment, pidpriєmnitctvo. Zbirnik naukovikh pratc. 2005 . №14 (1). S. 253 - 259.

8. Karpova T.S. (2012). Rol nalogooblozheniia subektov malogo biznesa $v$ razvitii sotcialnoi sfery. Finansovii i bankivskii menedzhment: dosvid ta problemi: tezi dopovidei i vistupiv XIV Mizhnarodnoi naukovoi konferentcii studentiv i molodikh vchenikh Donetck: Iugo- Vostok, 2012. C. 121-123. 